tized pulsar in supernova 1987A might nevertheless be detectable. The lowmagnetic-field millisecond pulsars would be weak sources in our scaling.

F. C. MICHEL

C. D. DERMER

Department of Space Physics and Astronomy,

Rice University, PO Box 1892,

Houston, Texas 77251, USA

1. Sturrock, P. A. Astrophys. J. 164, 529 (1971).

2. Arons, J. Astrophys. J. 248, 1099 (1981).

3. Cheng, A. F., Ruderman, M. \& Sutherland, P. Astrophys J. 203, 209 (1976)

4. Cheng, K. S., Ho, C. \& Ruderman, M. Astrophys. J. 300 500 (1986).

5. Michel, F. C. Theory of Neutron Star Magnetospheres (University of Chicago Press, 1991).

6. Michel, F. C. Astrophys. J. 383, 808 (1991).

\section{Aluminium and global warming}

SIR - The Intergovernmental Panel on Climate Change has overlooked two important greenhouse gases: $\mathrm{CF}_{4}(\mathrm{CFC}-14)$ and $\mathrm{C}_{2} \mathrm{~F}_{6}$ (CFC-116). These gases have atmospheric residence times in excess of 10,000 years and have strong absorption bands in the atmospheric window near 8 $\mu \mathrm{m}$ (ref. 1). Of the chlorofluorocarbons, the radiative forcing of $\mathrm{CF}_{4}$ and $\mathrm{C}_{2} \mathrm{~F}_{6}$ during the 1980 s was exceeded only by CFC-11, -12, -113 and HCFC-22 (ref. 2).

The only significant known anthropogenic source term for $\mathrm{CF}_{4}$ and $\mathrm{C}_{2} \mathrm{~F}_{6}$ is primary aluminium smelting. Various fluoride compounds, including $\mathrm{CF}_{4}$ and $\mathrm{C}_{2} \mathrm{~F}_{6}$, are produced during electrolysis of alumina $\left(\mathrm{Al}_{2} \mathrm{O}_{3}\right)$ dissolved in a molten cryolite $\left(\mathrm{Na}_{3} \mathrm{AlF}_{6}\right)$ bath ${ }^{3}$. A small, yet unidentified, natural source of $\mathrm{CF}_{4}$ is suspected. Fabian et al. $^{4}$ estimated global emission rates of 28,000 tonne $\mathrm{CF}_{4}$ and 3,200 tonne $\mathrm{C}_{2} \mathrm{~F}_{6}$ per year in 1987 . This suggests global average emission factors of about $1.6 \mathrm{~kg} \mathrm{CF}_{4}$ and $0.2 \mathrm{~kg}$ $\mathrm{C}_{2} \mathrm{~F}_{6}$ per tonne of primary aluminium production. These emission rates are consistent with aluminium industry estimates of $1.5-2.5 \mathrm{~kg}$ of $\mathrm{CF}_{4}$ produced and emitted to the atmosphere per tonne of aluminium, and an order of magnitude or so less of $\mathrm{C}_{2} \mathrm{~F}_{6}$ (ref. 5).

Using the band strengths reported by Hansen et al. $^{2}$, I estimate the global warming potential (GWP) to be between 10,000 and 11,000 for $\mathrm{CF}_{4}$ with 100 -yr integration time and without correction for the overlapping of absorption bands of $\mathrm{CH}_{4}$ and $\mathrm{N}_{2} \mathrm{O}$. F. Stordal, using a more detailed model, has estimated the $100-\mathrm{yr}$ GWP of $\mathrm{CF}_{4}$ and $\mathrm{C}_{2} \mathrm{~F}_{6}$ to be about 8,400 (personal communication). Lashof and Ahuja estimated that $\mathrm{CF}_{4}$ was responsible for $1.7 \%$ of the total warming potential of all global anthropogenic greenhouse gas emissions in $1985^{6}$.

Average $\mathrm{CF}_{4}$ and $\mathrm{C}_{2} \mathrm{~F}_{6}$ emissions are thus equivalent to the greenhouse contribution of about 15-20 tonnes of $\mathrm{CO}_{2}$ per tonne of aluminium. To the extent that $\mathrm{CF}_{4}$ and $\mathrm{C}_{2} \mathrm{~F}_{6}$ are produced during electrolysis cell anode effect, considerable variation in emissions from plant to plant would be expected as the frequency of anode effect varies by at least 10 -fold between smelters ${ }^{7}$.

$\mathrm{CF}_{4}$ and $\mathrm{C}_{2} \mathrm{~F}_{6}$ may be the most potent greenhouse gases being emitted in large amounts. Not only do they have a very large GWP, they also cause an essentially permanent alteration in greenhouse forcing. Aluminum smelting also results in large greenhouse gas emissions from production of the electricity consumed during smelting, and from $\mathrm{CO}_{2}$ produced during alumina reduction to aluminium metal. Alumina reduction, $2 \mathrm{Al}_{2} \mathrm{O}_{3}+$ $3 \mathrm{C} \rightarrow 4 \mathrm{Al}+3 \mathrm{CO}_{2}$, results, in practice, in emissions of between 1.5 and 2.2 tonnes of $\mathrm{CO}_{2}$ per tonne of aluminium. Aluminium smelters consume between 13 to $20 \mathrm{MWh}$ of electricity per tonne of aluminium depending on efficiency. Greenhouse gas emissions from producing this electricity vary from at least 22 tonnes of $\mathrm{CO}_{2}$ equivalent per tonne

\section{Leukaemia/Drosophila homology}

SIR - The sequence has recently been published $^{1}$ of a human complementary DNA clone encoded by a gene (designated $A M L 1$ ) that is rearranged in a translocation $(\mathrm{t}(8 ; 21))$ characterizing a subtype of acute myeloid leukaemia. No similarity was reported between the predicted polypeptide sequence and any known sequence. We find, however, that it is highly related to runt, one of the class of pair-rule genes that control morphogenesis in Drosophila melanogaster ${ }^{2}$. The region of best alignment spans 118 amino acids from positions $60-177$ in $A M L 1$ and from position 115-232 in of aluminium when the electricity is produced by a conventional coal-fired power plant to low levels for hydropower.

Cement is the only primary commodity, other than fossil fuels, specifically included in conventional tabulations of sources of greenhouse gas emissions. Yet the total greenhouse contribution from primary aluminium production appears to be greater than that from cement production on a global basis and can be tens of times greater in countries with a large primary aluminium industry based on fossil-fuel-generated electricity.

DEAN ABRAHAMSON

Humphrey Institute of Public Affairs,

University of Minnesota,

Minneapolis, Minnesota 55455, USA

1. Cicerone, R. S. Science 206, 59-61 (1979),

Hansen, J., Lacis, A. \& Prather, M. J. geophys Res. 94, 16417-16421 (1989)

3. Grjotheim, K. et al., Aluminum Electrolysis: Fun damentals of the Hall-Hérouit Process (Aluminum Verlag, Düsseldorf, 1982)

4. Fabian, P. et al J. geophys Res. 92, 9831-9835 (1987).

5. Haupin, W. E. in Production of Aluminium and Alumina (ed. Burkin, A. R.) (Wiley, Chichester, 1987)

Lashof, D. A. \& Ahuja, D. R. Nature 344, 529 (1990)

7. Øye, H. A. \& Huglen, R. J. Metals 42, 23-28 (1990).

intron boundary. It is tempting to speculate that it may represent a functional domain. Intriguingly, the $t(8 ; 21)$ breakpoints seem to cluster in the intron immediately downstream of this boundary.

Runt encodes a nuclear protein which is likely to be a transcriptional regulator, although it does not contain any of the structural motifs recognized in such factors, or a nuclear localization signal. $A M L 1$, however, does contain a cluster of basic residues at position 177-182 (four residues out of six being $\mathrm{K}$ or $\mathrm{R}$ ) which is a 'minimal' motif in transcription factors. This sequence would be

\title{
AMII
}

runt

AML1

runt

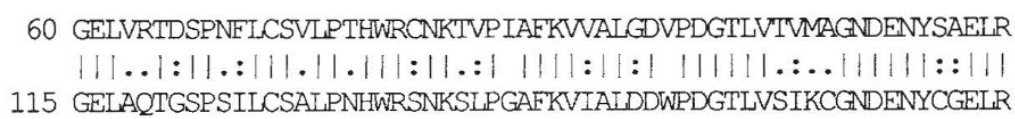
119 NATAAMKNQVARENDLREVGRSGRGKSFTLTITVFTNPPQVATYHRAIKITVDGPREPR $|.| \ldots||||||:|||||||||||||||||||||:|$ | | |:|.| : |||:|||||||||| Region of best alignment between human $A M L 1$ and $D$. melanogaster runt.

runt. Within this region, $73 \%$ of aminoacid residues are identical, a further $23 \%$ are conservative replacements, and the percentage nucleotide identity is $68 \%$. This is higher than the homology between the mouse proto-oncogene int-1 and its counterpart in Drosophila, wg (54\% amino-acid identity over 468 residues $^{3}$ ) and comparable to the homology between Drosophila and human homeoboxes. The region of homology also includes a perfect match of the A box of a putative ATP-binding site.

The region of homology between the Drosophila and the human sequences stops abruptly at a conserved exon/ disrupted by the $\mathrm{t}(8 ; 21)$. Thus, $A M L 1$ seems to be a structural homologue of runt in man. Its role in human development, particularly in haemopoietic differentiation, remains to be established.

ANTONIO DAGA JANE E. TIGHE FRANCO CALABI

MRC Leukaemia Unit,

Department of Haemotology,

Hammersmith Hospital,

London W12 ONN, UK

\footnotetext{
1. Miyoshi, $\mathrm{H}$ et al, Proc natn. Acad Sci. USA 88 10431-10434 (1991)

2. Kania, M. A. et al. Genes \& Dev. 4, 1701-1713 (1990)
} 3. Rijesewijk, F. et al. Cell 50, 649-657 (1987). 